\title{
LEGAL PLURALISM IN SETTLING INHERITANCE DISPUTES IN BESEMAH, SOUTH SUMATERA
}

\author{
Dewi Sukarti \\ Faculty of Sharia and Law UIN Syarif Hidayatullah Jakarta \\ Jl. Ir. H. Juanda 95, Ciputat, Jakarta \\ E-mail: dsukarti@gmail.com
}

\begin{abstract}
Abstrak: Pluralisme Hukum dalam Penyelesaian Sengketa Waris di Besemah, Sumatera Selatan. Persoalan warisan hadir dalam setiap tradisi, mulai dari tradisi-tradisi besar hingga tradisi-tradisi kecil karena sebagaimana pendapat Vinogradoff bahwa warisan diberikan setelah kematian orang tua agar anak-anaknya mampu menjalani hidupnya setelah orang tua mereka meninggal. Karena itu, hukum Islam sebagai tradisi besar dan hukum adat Besemah sebagai tradisi kecil menetapkan aturan tentang warisan. Kedua sistem hukum ini dipraktikkan di Sumatera Selatan, khususnya di kelompok etnik Besemah. Tradisi warisan Besemah dipraktikkan secara luas di masyarakat Besemah. Namun, ketika ada perselisihan tentang warisan yang diajukan ke pengadilan, terdapat dua pengadilan yang berwenang untuk menyelesaikan perselisihan tersebut. Pengadilan Negeri mengadili unsur adat dari warisan (budel) dan kemungkinan unsur pidana dalam perselisihan waris tersebut. Namun ketika perselisihan diajukan ke Pengadilan Agama, hakim akan mengacu pada hukum Islam. Dengan begitu, negara mengakui pluralisme hukum waris.
\end{abstract}

Kata Kunci: budel, jurai, warisan, Pengadilan Agama, Pengadilan Negeri

\begin{abstract}
Legal Pluralism in Settling Inheritance Disputes in Besemah, South Sumatera. Inheritance issue is present in almost every tradition, ranging from great traditions to little ones because as Vinogradoff view that inheritance is given after the death of parent(s) in order that his/her children are able to lead his/her life after the his/her parents passed away. Therefore, Islamic law as great tradition, and Besemah's customary law as little tradition lay rules on inheritance. The two legal systems are practiced in South Sumatera, especially in Besemah ethnic group. Besemah's inheritance tradition is practiced widely in the society of Besemah, but when there is a dispute on inheritance adjudicated to court, there are two courts authorized to settle the dispute. State court tries the traditional element of inheritance (budel) and the assumed criminal element in the dispute. But when the dispute is booked to religious court, judges would refer to Islamic law. Here the state acknowledges pluralism of law of inheritance.
\end{abstract}

Keywords: budel, jurai, inheritance, religious court, state court

\section{Introduction}

It has been widely known that Indonesia is a home for a number of ethnic groups. A quite old study, "Daftar Sementara Suku-suku di Indonesia berdasarkan pada Klasifikasi Letak Pulau dan Kepulauan", by M.A. Jaspan that mapped out Indonesian society in 1959 listed that there were 49 ethnic groups in Sumatera, 7 groups in Java, 73 groups in Kalimantan, 117 groups in Sulawesi, 30 groups in Nusa Tenggara, 41 groups in Maluku-Ambon, and 49 groups in Irian Jaya (now Papua). ${ }^{1}$

Earlier study conducted by C. van Vollenhoven in 1925 is still widely quoted in the studies on customary

Received: 23rd July 2012, revised: 16th October 2012, accepted: 28th October 2012.

1 Soerjono Soekanto, Hukum Adat Indonesia, (Jakarta: PT RajaGrafindo Persada, 2003), p. 21-32. law. According to Vollenhoven, Indonesia is a home for 19 groups of customary law ${ }^{2}$ as follow: (1) Aceh (Aceh Besar, West Coast of Aceh, Singkel, Simeulue); (2) GayoAlas and Batak; (2.a) Nias; (3) Minangkabau (Padang, Agam, Tanah Datar, Limapuluh Kota, Kampar, Kerinci); (3.a) Mentawai; (4) South Sumatera (BengkuluRejang; Lampung-Abung, Peminggir, Pubian, Rebang, Gedongtataan, Tulangbawang; PalembangAnak Lakitan, Jelma Daya, Kubu, Pasemah, Semendo); (4.a) Enggano; (5) Malay (Lingga Riau, Indragiri, Sumatera East Coast, Banjar); (6) Bangka and Belitung; (7) Kalimantan (Dayak, Western Kalimantan Barat, Kapuas Hulu, Southeast Kalimantan, Mahakam Hulu, Pasir, Dayak Kenya, Dayak Klematan, Dayak Landan dan Tayan, Dayak-Lawangan, Lepo-Alim, Lepo-Timei,

\footnotetext{
${ }^{2}$ Soerjono Soekanto, Hukum Adat Indonesia, p. 19-20.
} 
Glatt Panjang, Dayak Maanyan-Patai, Dayak MaanyanSiung, Dayak-Ngaju, Dayak-Otdanum, DayakPenyabung Punan); (8) Minahasa; (9) Gorontalo; (10) Toraja (Sulawesi Tengah, Toraja, Toraja yang berbahasa Baree, Toraja Barat, Sigi, Kaili, Tawaili, Toraja Sadan, To Mori, To Lainang, dan Kepulauan Banggai); (11) South Sulawesi (Bugis, Bone, Goa, Laikang, Ponre, Mandar, Makassar, Selayar, Muna); (12) Ternate (Ternate, Tidore, Halmahera, Tobelo, Pulau Sula); (13) Maluku (Ambon, Banda, Uliaser, Saparua, Buru, Seram, Kepulauan Kei, Kepulauan Aru, dan Kisar); (14) Irian/ Papua; (15) Timor (Timor, East Timor (now Timor Leste), Central Timor, Mollo, Central Sumba, East Sumba, Kodi, Flores, Ngada, Roti, Savu Bima); (16) Bali-Lombok (Bali, Tanganan Pagringsingan, Kastala, Karangasem, Buleleng, Jembrana, Lombok, Sumbawa); (17) Central Java, East Java, Madura (Central Java, Kedu, Purworejo, Tulungagung, East Java, Surabaya, Madura); (19) Royal regions of Surakarta-Yogyakarta; (20) West Java (Parahyangan, Sunda, Jakarta, Banten).

Thus, based on the Vollenhoven's grouping, Besemah, that was called Pasemah by Dutch is one of the ethnic groups in South Sumatera that has a unique customary legal system especially in the customary inheritance law.

\section{Description of Besemah}

Besemah is a name used by the Besemah society to refer themselves. Having difficulty to mention the word "Besemah" Dutch writers call it Pasemah, while Portuguese call it Passumah. ${ }^{3}$

In an article entitled "Sekilas Sejarah Besemah", Besemah is known as a name of an ethnic on the highland around Dempo Mountain (3159 ms high) and Mountainous range hills (400-900 ms high), South Sumatera. Besemah ethnic is surrounded by other ethnics such as Semendo, Lintang, Gumay, and Empat Lawang. Sometimes, however, Besemah is directly connected geographically with the District of Lahat. This means that Besemah is considered to cover also ethnics surrounding the Besemah, such as Lintang. The Besemah (Pasemah) itself, according to some sources consists of Pasemah Lebar (in the District of Lahat), Pasemah Ulu Manna (in the Southern part of Prov. Bengkulu), Pasemah Ulu Lintang (in the Northwest, in District Empat Lawang), Pasemah Air Keruh (located far away behind the berada jauh di Mountain chain hills, in District Empat Lawang). Populations of the last three Pasemahs come from Pasemah Lebar. They emigrated to surrounding regions, namely ex-sultanate of Palembang

\footnotetext{
3 "Sekilas Sejarah Besemah" dalam http://besemah.blogspot. com/2007/06/sekilas-sejarah-besemah.html.
}

and British colony in Bengkulu, and adapted with the people of the regions. Pasemah Ulu Manna itself, was a part of Bengkulu Residency during the Dutch colonial era. The most appropriate region for the location of the ethnic of Besemah is in the border of South Sumatera and Bengkulu and in the border of South Sumatera and Lampung, viz in the Districts of Lahat, Pagar Alam (as the center of Besemah), Empat Lawang, and Muara Enim in South Sumatera and Curup in Bengkulu, as well as Besemah Palas in Lampung. ${ }^{4}$

The location of Besemah can be traced back to the centuries 15 to 17 during which the World of Besemah (Jagat Besemah) was one of the big kingdoms other than Palembang. The World of Besemah was led by Ratu Singe Bekurung (the 10th king of Jagat Besemah). Meanwhile Palembang was led by Pangeran Sido ing Kenayan (the 9th king of Palembang). ${ }^{5}$ In the middle of 17 th century, Pangeran Sedo Ing Kenayan and Depati Karang Udara as rulers of Palembang and Ratu Singe Bekurung as the ruler of Besemah made an agreement on borders of Besemah and Palembang. The point in the agreement was that the upstream part of South Sumatera becomes the region of Besemah, as for the downstream becomes the region of Palembang. ${ }^{6}$ Thus, the separation of the uluan from the iliran Palembang can be traced back to this agreement.

Upstream and Downstream that literally means the environmental orientation based on the stream of river. Upstream means where the river begins while downstream means where the river ends. It is a natural law that river streams from a higher land to lower land. Thus, upstream and downstream indicates the situation of landscape of south Sumatera that consists of highlands and lowlands with rivers flowing water from the highlands to lowlands. The connotation of upstream and downstream extends to language, customs, and lifestyle in which upstream people are quite distinct from those in the downstream. ${ }^{7}$

As the environment where people of Besemah live is tropical forests of the mountainous range hills in South Sumatera, majority of the people of Besemah live on their natural riches, mainly on paddy, coffee, and rubber plantations. People of Besemah have already known paddy cultivation system before they know coffee and rubber plantations, as ibu Asnah related:

\footnotetext{
${ }^{4}$ Ahmad Bastari Suan et al., Besemah: Lampik Mpat Mardike Duwe, (Palembang: Pesake-Pemkot Pagaralam, 2008), p. 1, 30-31.

${ }^{5}$ Ahmad Bastari Suan et al., Besemah: Lampik Mpat Mardike Duwe, p. 72-73.

${ }^{6}$ Bastari Suan et al., Besemah: Lampik Mpat Mardike Duwe, p. 74.

${ }^{7}$ Barbara Watson Andaya, To Live As Brothers: Southeast Sumatra in the Seventeenth and Eighteenth Centuries, (Hawaii: University of Hawaii Press, 1993), p. 13-17.
} 
The people of Mulak $\mathrm{Ulu}^{8}$ had just known coffee cultivation after some people from Mulak went to Rawis, Semendo for daily paid works. They cleared coffee fields of Semendo people from grass or picked their coffee crops. Returning home from travel to Semendo, people of Mulak started to imitate the coffee cultivation. Previously here in Mulak, farmers cultivated rice, either dry rice field or wet rice field. ${ }^{?}$

As for rubber plantation, although it had been known since Dutch colonial era, it is not as highly popular as paddy and coffee crops. If along the slope of hills is paddy and coffee fields, rubber field is only in small number, sometimes rubber plantation is only as a variation in a coffee field.

Most of the Besemah people speak Middle Malay. But due to cultural contacts with Palembang, some of the Besemah people, particularly those who live in cities, such as the cities of Lahat, Pagar Alam, and Muara Enim, speak the language of Palembang. The adoption of the latter as the lingua franca in the cities of Besemah is primarily caused by inferior feeling if they speak the Middle Malay (which is pejoratively called village language) in relation to an a priori assumption that the Palembang culture is higher than that of Besemah. Jeroen Peeters wrote that "as a result of rising economic transportation between merchants from Iliran and the societies in the Uluan, the traditional chiefs and rich villagers liked to imitate urban people with their higher culture." ${ }^{\prime 10}$ It is in the context of imitating the Palembang's culture which is considered higher than their own that the people of Besemah living in cities prefer speaking the Palembang language to their own mother tongue (Middle Malay).

The Besemah people are Muslims. But due to geographical and historical factors, Islam that came to the society of Besemah is limited to its ritual aspects, and not all of the compulsary rituals are performed fully by the society. Part of Islam's social aspects that comes to Besemah is marriage. Islamic marriage has been known in Besemah since the Syarikat Islam came to masuk to the region, around 1940s or 1950s, when many married couples asked for Islamic marriage. ${ }^{11}$

Until 1980s, I saw some people professed animism, such as practicing "bertarak" or secluding to mount top or other sanctuaries in order to be given a keris by some one in mystery. This practice shows the people's religious

\footnotetext{
${ }^{8}$ Name of one of marga in Besemah.

${ }^{9}$ Asnah, a resident of Sengkuang-Mulak Ulu, interview, 1 Februari 2010.

${ }^{10}$ Jeroen Peeters, Kaum Tuo-Kaum Mudo: Perubahan Religius di Palembang 1821-1942, (Jakarta: INIS, 1997), p. 83.

${ }^{11}$ Husni Rahim, "Islam di Pedalaman Palembang", seminar on "Peradaban Besemah sebagai Sarana Membangun Peradaban Bangsa", Jakarta, Mei 2010, p. 1.
}

practice is mixed with dynamism and animism.

Another thing that shows the influence of Islam in Besemah is just a little is that there are hardly Muslim preachers or ulama at regional level coming from Besemah, most of the preachers or ulama who teach in Besemah come from Minang. ${ }^{12}$ At present if there are ulama known nationally as Palembang origin is of Arab descent, meaning that they come from Palembang (Iliran), not from Besemah (Uluan).

Only in 2000s that the people of Besemah have Islamic boarding schools (pesantren) in Lahat and Pagar Alam. Although the Besemah's public interest in sending their children to pesantren is still low, the existence of pesantren may be able to improve the Islamicity of Besemah next days.

Values of Besemah people are based on their cohesive character. This cohesiveness is originated from the Besemah's world view of sumbai and jurai. Sumbai is a unity of traditional community based on genealogy. The Besemah's ancestor (Puyang Atung Bungsu) had six descendants (sumbai), therefore Besemah is also known as Besemah bekelindan enam (Besemah that consists of six sumbai), namely: Sumbai Ulu Lurah, Sumbai Besak (Besar), Sumbai Mangku Anom, Sumbai Tanjung Ghaye (Tanjung Raya), Sumbai Penjalang, and Sumbai Semidang. ${ }^{13}$

As for jurai in Besemah people means descendants, either of the same sumbai or of the other sumbai. For example, the people of Sengkuang village and those of Karang Lebak village are jurai of ancestoral father of Klung Lah and identify themselves as parts of Sumbai Besak Suku Mulak Ulu or Marga Mulak Ulu. The chiefs within the sumbai and jurai are jurai tuwe (the oldest male descendant), whose chiefdom is guided by customary law. Therefore a jurai tuwe also acts as a functionary of Besemah tradition.

The hierarchy of genealogical structure of Besemah people:

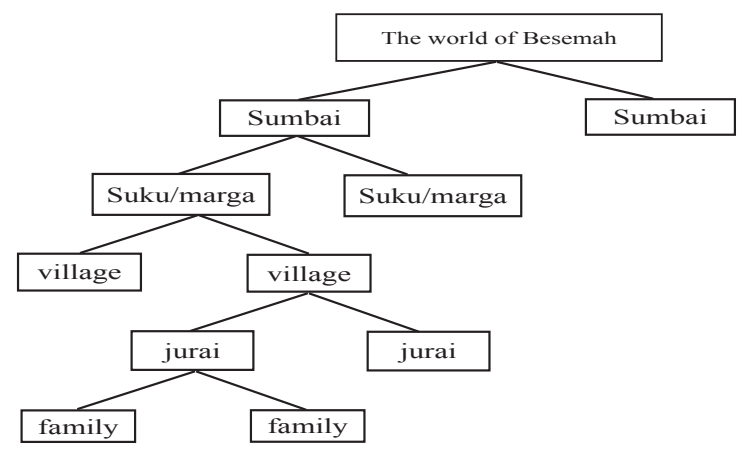

${ }^{12}$ Husni Rahim, "Islam di Pedalaman Palembang”, p. 1.

${ }_{13}$ Ahmad Bastari Suan et al., Besemah: Lampik Mpat Mardike Duwe, p. 13. 
Before 1939 the Besemah people viewed that people of the same sumbai were brothers and sisters, and therefore were prohibited from marrying couple from the same sumbai, as said in a proverb of Besemah people "around Mount Dempo and along river Lematang that links to river Inim (river Enim), and river Lintang links to river Musi Musi, an marriage of a couple within the same sumbai is prohibited, because they are still of the same family." 14

But the cohesiveness of the people of the same sumbai started to reduce after the sumbai system fell in 1939 as a result of socio-cultural change, either due to migration factor, or an ifluence of Islam that does not recognize the sumbai's marriage prohibition. But the most significant reason is the administrative change from administration of genealogical marga to that of territorial sub-district. ${ }^{15}$ As the marga administration changed to sub-district administration, the societal structure changes from the society based on genealogy to the society based on territory. As a corollary of all this is that the migration to Besemah land is open for people from different ethnics such as Javanese and Chinese and even they can marry a Besemah man and woman. Therefore their descendants are not purely Besemah any more and since then sumbai system collapsed.

To certain extent, however, the Besemah values remain prevail as the following: ${ }^{16}$

tegakkah ganti nga tungguan (enforce tolerance and care)
or seganti setungguan (feeling of unity and tolerance)
tegakkah adat lawan ukum (enforce tradition and law)
seanak bujang, seanak gadis (all boys and girls)
bekelaway, bemuanay (are brother and sister)
beading, bedengasanak (having younger or older
siblings)
tuwe ngipat, kecik mekhipat (the older one loves their
juniors, and the younger ones respect their seniors)
utang mbayar (should you have debt pay your debt)
piutang tanggapi (should you have claim do the claim)
serame bekhagih (collective belongings should be divided
evenly)
ndepat mbalik (should you find someone's thing you
return it to him/her)
nde ukhang, nde ukhang (someone's belongings are his/
hers)
nde dikhi, nde dikhi (your belongings are yours)
pacak ulak, diulak-i (what you can do, please do)
pacak jangan, dijangani (what you can abstain from, do
not)
segale-gale jangan "ige" (everything should not be
excessive)

${ }^{14}$ Ahmad Bastari Suan et al., Besemah: Lampik Mpat Mardike Duwe, p. 44.

${ }^{15}$ Jumhari, "Refleksi Historis Jati Diri dan Identitas Budaya Orang Besemah” in http://wisata-kami.blogspot.com/2009/05/refleksi-historis-jati-diri-dan-identitas-budaya-orang-pasemah.html.

${ }^{16}$ Ahmad Bastari Suan et al., Besemah: Lampik Mpat Merdike Duwe, p. 102-104. mpuk galak, tahani dikit (although you want something control your want a bit)

mpuk dindak, bidikah dikit (although you don't want to, try to do a bit)

janji nunggu, kate betaruh (your promise awaits and words bet)

tumbang dide sangi jawekah (should you fall do not make the others fall)

sembak wi pengarang rakit (like a rattan joining bamboos for a raft)

timbul tenggelam same-same (up and down together) tekhendam same basah (when they are under water they are equally wet)

ngerapung same anyut (when they are floating they are equally washed away)

It is this cohesive value that is reflected in inheritance in Besemah. But that is the ideal (das Sein), the norm. In practice (das Sollen) there may be deviations from the norms as shown in inheritance disputes.

\section{Islam of Besemah}

Different from Palembang and other downstream areas of South Sumatera that experience the Islamization process earlier than the upstream areas, viz around the 15th/16th century of common era, Besemah was Islamized much later, viz in the 19th century. ${ }^{17}$ This is due to the fact that communication between Islam and Palembang and the other downstream areas was easier than Besemah. The reason for the difficulty of communication between Palembang and Besemah among other things was the difficulty to reach Besemah at that time, that took more than a week journey through rivers or through forests with simple transportation. This condition made the interaction between Besemah and Palembang and downstream areas difficult. ${ }^{18}$

As a result of the difficulty of cultural contact between Islam and Besemah was the slow process of Islamization in Besemah. Although the Dutch colonial government implemented the policy of strengthening the cadres of Islamic institution during the era of transition from indirect governance to direct governance between 1853 and 1866, yet Islamic infrastructure in the upstream in general and Besemah in particular was weak. This was marked by small number of mosques in the upstream. In the upstream, the mosques function not only as a worship place but also as the only place to teach Islam. But mosques were only build nearby the houses of the marga chiefs. Therefore, according to the colonial's report, except the marga chief (pasirah) only rarely that people performed prayers in the mosques. ${ }^{19}$ Consequently, most of the people in the upstream did

\footnotetext{
${ }^{17}$ Husni Rahim, "Islam di Pedalaman Palembang (Besemah)", p. 1.

${ }^{18}$ Jeroen Peeters, Kaum Tuo-Kaum Mudo, p. 77.

${ }^{19}$ Jeroen Peeters, Kaum Tuo-Kaum Mudo, p. 77.
} 
not have an access to mosques and Islamic teaching. A concrete proof was found in a census report of 1847, by the head of the division of Musi Ulu, Raden Demang Abdurrahman, that noted that there were only 17 mosques in more than 100 settlements in the upstream of River Musi or out of 15 marga in Upstream Musi, only 5 marga did have mosques. ${ }^{20}$

This census was followed up by the colonial government's policy by encouraging the building of mosques, that in every village should a mosque be built. As a result, between 1870 and 1880, in almost every village in the upstream mosques started to be built. This is followed up with the government's policy of creating religious bureaucracy that appointed khatib or ketip (the chiefs of religious affairs in the village level) and lebai penghulu (the chiefs of religious affairs in the marga level). Nonetheless, this religious bureaucracy did not cover all areas in the upstream. In 1870, out of more than 222 marga in the Residency of Palembang, only 142 marga that had a lebai penghulu, and out of 1200 villages only some that had khatib. ${ }^{21}$

In order to improve the quality of religious bureaucrats, the government required that khatib be literate to Jawi letters (Malay Arabic). In addition to that, khatib were obliged to teach reading the quran to youth in villages. As for lebai penghulu, a pasirah had to send a candidate of lebai penghulu to be examined by Pangeran Penghulu Natagama (the highest rank of religious office) in Palembang before being installed by the Resident. The lebai penghulu were authorized to arrange Islamic marriages and inheritance, as well as the main objective intended by the colonial government, viz to struggle against the practice of jujur marriages (marriage by paying brideprice). ${ }^{22}$

As the colonial government's objective of erecting mosques and instituting religious bureucracy was not genuine, but full of political interests, when it was perceived that the government's support for Islam was considered no longer important, the inducement for advancing Islam in Palembang stopped. After the creation of a direct government in 1853 the government's advancement of Islam was ended up. As the power of the Dutch colonial bureaucracy in Palembang had been strong, the colonial's need for a coalition with Islam reduced. This tendency can be seen in, for instance, the revocation of the office of hoofddivisie that was replaced by a Dutch controller. After the downfall of the sultanate of Palembang into the clutches of the Dutch in 1821, the government created a governing

\footnotetext{
${ }^{20}$ Jeroen Peeters, Kaum Tuo-Kaum Mudo, p. 77.

${ }^{21}$ Jeroen Peeters, Kaum Tuo-Kaum Mudo, p. 77.

${ }^{22}$ Jeroen Peeters, Kaum Tuo-Kaum Mudo, p. 79.
}

corps of the chiefs of division, who were appointed from priyayi (royal circles) and mantri (low ranking government). Being unnoticed by the Dutch, these chiefs of divisions coopted the authority to Islamize the societal cultures. This cultural Islamization strategy was not only conducted persuasively, but also by legal force in order that the Muslim society obey Islamic rituals, for example the order of Sammaniyah was introduced in villages. The pasirah and their people would be fined by the chief of division should they were absent in the gatherings of trainings of ratib dan zikir held by the mystic order. It is in consideration of this development, the office of the chief of division was decided to be revoked in 1864 and the function of the office was taken over by the Dutch controller. ${ }^{23}$

The Dutch's next strategy was to disconnect the cultural connection between city and village (viz: Islam dan the upstream) in the form of revoking the obligation of the candidate of lebai penghulu to have testing before Pangeran Penghulu Natagama in Palembang. By the Resident's decision No. 426 on 24 July 1873 , this revocation started to prevail. The purpose of the revocation was to impede the influence of Islamic law on customary law. ${ }^{24}$

The consequence of the Dutch policy, the upstream's societal knowledge on Islamic law remained low. Most of the officers of religious affairs knew Islamic law only a little, therefore the influence of figh on customary law was just a little. This is why although in the villages there were penghulu and khätib but the status quo between customary law and Islamic law was unchanged, different from that in other parts of Indonesia that assimilate Islamic law and customary law the penghulu and khätib in the upstream did not do the same. Even in Marga Court (Rapat Marga), the lebai penghulu often strengthened the decisions of chiefs of customs in spite of the fact that the decisions were clealy against Islamic law. ${ }^{25}$

Then in 1881, Pan-Islamism propaganda brought about series of the arrests of a number of noble ulama in the capital of Palembang and the discontinuance of Islamization process in the hinterland. According to Peeters, any forms of contact between Islam, the capital, and the hinterland were disconnected due to the Dutch's fear of this Pan-Islamism. That is why although after 1873 Chinese merchants were permitted to settle in the upstream, Arabian merchants were prohibited from settling in the outside of the capital of Palembang. ${ }^{26} \mathrm{Next}$,

\footnotetext{
${ }^{23}$ Jeroen Peeters, Kaum Tuo-Kaum Mudo, p. 79.

${ }^{24}$ Jeroen Peeters, Kaum Tuo-Kaum Mudo, p. 79.

${ }^{25}$ Jeroen Peeters, Kaum Tuo-Kaum Mudo, p. 79-80.

${ }^{26}$ Jeroen Peeters, Kaum Tuo-Kaum Mudo, p. 86.
} 
based on the decision of the Resident of Palembang no. 82 on 28 February 1882, teachers of Islamic lessons who came from Palembang were prohibited from coming to villages. Repeated requests from teachers of Islamic lessons in the capital to stay in the villages were always rejected by the Dutch after 1882 . In order to impede any single unwanted influence from the capital, the Dutch strengthened religious bureaucracy in villages by giving full control over (rural) mosques to khätib and penghulu. Ony the local officers of religious affairs who were permitted to lead Friday prayers. In addition to that, any single religious teachings had to be under the close control of khātib. ${ }^{27}$

It is these geographical and historical background that Islam in Besemah did not much affect Islamic legal aspects. In spite of the fact that mosques had been built in every village, the activities of mosques vary, depending on the officers of the mosques. Before 1980s, the affairs of mosques were managed by khätib (ketip). The tasks of khätib include taking care of the mosques, starting from leading daily prayers, reading religious sermons in collective prayers, leading the rituals of people's death, till marry off people and divorce them before the introduction of the Act No. 1/ 1974 that lays down the rule that require the marriage be registered in an office of subdistrict religious affairs (Kantor Urusan Agama) and divorce be conducted before a religious court for Muslims. Since 1980s, the office of khatib was replaced with the office of public welfare (Kesejahteraan Rakyat) whose tasks are the same as that of khätib except legal marriage and divorce. But the level of Islamic legal knowledge of this officer is not deep. The contents of their sermons cover rituals only, they never talk about such other aspects of Islam at Islamic inheritance.

The ritual aspects delivered in the sermons of the office of public welfare are not fully implemented in the villages. From bird's eyes view in some villages I found out that not many of people of Besemah who perform daily compulsary prayers and usually only seniors who fast full month in Ramaḍan.

Such a condition of Besemah affect its system of inheritance. The system of inheritance applied in Besemah society is dominated by customary law of inheritance.

The Besemah people, however, also use the term of warisan, stemming from the word waris in Arabic. But Islamic inheritance known by society is just symbolic, they do not know its content and practice. Thus, although they use the term "warisan" that they borrow from Islam, they do not apply Islamic inheritance.

\footnotetext{
${ }^{27}$ Jeroen Peeters, Kaum Tuo-Kaum Mudo, p. 86.
}

\section{Inheritance Disputes}

According to Laura Nader dan Hary Todd, dispute is the highest phase of social conflict. Before a conflict reaches the phase of dispute, the conflict undergoes the phases of pre-conflict (grievance) and conflict. In the pre-conflict phase, someone feels injustice and complain about it (monadic). This phase may rise to conflict, but also may go down by lumping it or conflict avoidance. Next, when the person who is harmed tells of his/her hurt to the party who transgresses his right, this phase has arrived at the phase of conflict (dyadic). This phase may escalate to the phase of dispute but through negotiation with opponent or coercion the phase may calm down. The peak phase is dispute, i.e. the conflict brought to public. This phase involves a third party who is authorized to help settle the case (tryadic). ${ }^{28}$ According to Gulliver, a dispute occurs only if the complaining party or someone on his behalf raises the conflict from the dyadic debate to the conflict that enters a public field. This proceeds intentionally and actively in order to gain the intended objective, namely a measure about the intended claim. ${ }^{29}$

Considering the tolerant value of the Besemah people, as reflected in the teachings of their ancestor, their inheritances disputes rarely come to the surface, let alone be settled in courts. The Besemah people prefer self control in order not to involve in open conflict among brothers, athough they are aware of inner rejection of illegal occupancy of inheritance conducted by their brothers or relatives. The effect of their self control is inner conflict in the form of mumbling or talk to other people about the illegal occupancy of inheritance by illegal heirs.

The inheritance disputes in Besemah do not come to the surface are due to a social value that negativate people who quarrel over inheritance, let alone if the dispute is booked to court. A dispute in inheritance is considered embarrassing and the party who initiates the quarrel over inheritance is considered greedy (in local language, cikil, canggih). Mr. Sata, a former pasirah of Mulak Ulu said that in Besemah, "It is just the greedy people that book inheritance disputes to courts". ${ }^{30}$

${ }^{28}$ Sulistyowati Irianto, Perempuan di antara Berbagai Pilihan Hukum: Studi mengenai Strategi Perempuan Batak Toba untuk Mendapatkan Akses kepada Harta Waris melalui Proses Penyelesaian Sengketa (Jakarta: Yayasan Obor Indonesia, 2012), p. 53-54.

${ }_{29}$ T.O. Ihromi, "Beberapa Catatan mengenai Metode Kasus Sengketa yang Digunakan dalam Antropologi Hukum” dalam T.O. Ihromi (Ed.), Antropologi Hukum: Sebuah Bunga Rampai, (Jakarta: Yayasan Obor Indonesia, 2001), p. 210.

${ }^{30}$ Sata, mantan pasirah Mulak Ulu, Interview, Mulak Ulu, 9 Februari 2010. 


\section{Plural Inheritance Law}

Legal pluralism is acknowledging the existence of some legal systems that rule particular social field in a region. A strong legal pluralism acknowledges the existence of different legal spaces that influence each other and mix in the mind and behavior of a society. ${ }^{31}$

Although majority of Besemah people are moslems, the influence of customs on inheritance is strong, as there are two legal systems relating to inheritance of Besemah people, namely Besemah inheritance custom and Islamic inheritance law people may settle their inheritance quarrel in a religious court or a state court. For Besemah people, going to a religious court or state court is a matter of option, as shown in the case registered no. 122/ Pdt.G/ 2008/ PA.Lt that was once adjudicated to state court of Lahat for the case of the same property but with different defendant. That is also the case no. 0397/Pdt.G/2009/PA.Lt, that was once adjudicated to the state court of Lahat but was rejected by the judges. After having been rejected by the state court because of unadequate evidence and the fact that it was irrelevant to law in its law suit, the plaintiff adjudicated his suit to the religious court of Lahat, but again the suit was rejected.

\section{Islamic Law of Inheritance (The Compilation of Islamic Law)}

Islamic Law of Inheritance applied in Besemah is the Islamic law of inheritance written in the Compilation of Islamic Law. In the Compilation of Islamic Law, inheritance law is contained in book II. Book II or Inheritance Law contains 6 chapters and 44 articles, starting from article 171 until article 214. Chapter I is about general rule that contains definitions; chapter II lays down the rules on heirs; chapter III on the rules of the amount of inheritance that would be received by the heirs; chapter IV on aul and rad; chapter V on bequest; and chapter VI on endowment (hibah). ${ }^{32}$

In line with article 174 of the Compilation of Islamic Law, heirs consist of cognation group and marital group. The cognation group consists of father, mother, son, daughter, brother, sister, uncle, grand father, and grand mother. As for the marital group of heirs consists of husband or wife. Should all the heirs be present, those who would not receive portions are children, father, mother, wife, and husband.

\footnotetext{
${ }^{31}$ Anne Griffith, "Legal Pluralism", in Reza Banakar dan Max Travers, An Introduction to Law and Social Theory, (Oxford: Hart Publishing, 2002), p. 302.

${ }^{32}$ Abdurrahman, Kompilasi Hukum Islam di Indonesia, (Jakarta: Akademika Pressindo, 1995), p. 155-165.
}

The Compilation of Islamic Law is only impemented in Besemah if the dispute is adjudicated to the religious court. In trying the inheritance cases adjudicated to them, djudges of religious court would refer to the Compilation of Islamic Law. But from my study on the verdicts of the religious court of Lahat in 2008-2009, only three verdicts were found, namely verdict no. 122/ Pdt.G/ 2008/ PA.Lt closed by NO (Niet Onvankelijk verklard); verdict no. 43/Pdt.G/2009/PA.Lt was closed by peaceful agreement outside the court room; and verdict no. 0397/Pdt.G/2009/PA.Lt that accepted some of the demands of the plaintiff, on the request for the court's decision on the actual heirs; and reject the rest of the claim of the plaintiff, namely the plaintiff's claim for a portion of inheritance because the plaintiff had once been given a portion by the paintiffs parents and now the property left has all been distributed.

Thus, in order to know which articles of the Compilation of Islamic Law quoted by the judges, I focus my study on verdict no. 0397/Pdt.G/2009/ PA.Lt. In their legal consideration, the judge considers that the position of the plaintiff, the defendants as children and wife of the late A. HAN bin H. JEN are the heirs that no defendant objected to the position meaning the defendant acknowledges it; and considers based on the fact, that as long as the position of the parties are concerned as the heirs must be accepted. This consideration is in accordance with articles 171 (c) and 174 of the Compilation of Islamic Law.

Afterwards, the judges refer to article 185 pf the Compilation of Islamic Law, the umpteen position of the heir in the lawsuit because he has been dead earlier can be replaced by his children. Then the judges consider the trial fact stating that one of the heirs had been previously given two lots of soil by her parents that was confirmed by the plaintiff, the judges also refer to article 211 of the Compilation of Islamic Law laying the rule that "the bequest given to his/her children can be counted as inheritance". Bequest means inheritance given by an inheritor before the inheritor died. Whereas the meaning of "can be counted" is the property bequeathed can be considered a part of inheritance.

Then in their verdict, the judges decided that the heirs in this case are all the uterine children born of the inheritor with the first wife, consisting of nine children; and the inheritor's second wife because the first wife had been divorced before the inheritor died.

\section{The Besemah's Customary Law of Inheritance}

According to the Besemah's tradition, inheritance is distributed to children of the inheritor only. Sons are 
more favorable than daughters. Sons are more favorable to be heirs because sons hold a central position in Besemah as Besemah is one of ethnics that hold a patrilinial culture. It is patrilinialism that makes budel distributed to the oldest son of the oldest male heir or the only son of the oldest male heir. If there is no male heir, female heir can be considered on condition that she is the oldest daughter in order for her to receive budel.

In a patrilinial society, like in Besemah, a mother is not an inheritor nor a heir. She may give gifts, like gold jewelry, to her children before her children get married evenly. Mrs. Marhamah, for example, received a number of gold jewelry from her mother before she got married by berlaki, she brought the gifts with her. Then, when her son would travel to Java she gave her son a 24 carats gold hairpin, and her daughter a 24 carats gold necklace. The gifts were then sold by her children for their own living. The gold jewelry as such is not considered inheritance, but a gift for the children's future need.

When the mother's husband dies, she would not receive inheritance from her husband. Although she toils to make a living and collect wealth during her life with her husband, she just keeps what she jointly makes for the actual heirs, her children or particularly her oldest son. Next during her old age, the mother would live alone or with one of her children in his husband's village without property anymore except what she enjoys with whom she lives.

\section{Time and Method of Inheritance Distribution}

According to the custom of Besemah inheritance is distributed during the lifetime of the inheritor. The inheritor just says orally to his heirs which of his wealth that will be inherited to his heirs. Usually inheritance is transferred after his son has led a marital life because the inherited wealth can be benefitted to support the heir's new family.

But in some cases, there are inheritors or parents that do not transfer the inheritance (usually budel) to his son although the son has started a marital life, either on consideration that the inheritor is still alive or on consideration that the inheritor still makes a living on the land to be inherited. If the heirs have good careers this would not be a problem because they can make a living on their career. But the case would be different if the heirs do not have career, but as farmers who depend their living on farmland. In many cases, the heirs are forced to ask other people who have unworked farmland for permission for being sharecroppers in their farmland with the share system of 50:50 after paying the process and harvest costs or only small part of the crops.

As for the method of inheritance distribution according to the Besemah tradition is neither proclaimed before all the heirs nor written down as a will. Inheritance distribution is not proclaimed clearly before all the heirs inasmuch as the heirs have already been aware of their positions in their family, whether as the oldest son of the inheritor or not. If so the heir has the right of budel and would receive the largest portion of inheritance of joint property of his parents. Otherwise, if a man is the youngest son his portion depends on whether his oldest brother deigns to give him some and whether his parents have joint property, or whether the heir is a daughter that her position depends on her parents' grace that can give her a precious gift such as gold before she got married or a piece of land that in the tradition would not be given to a daughter but because her husband does not have sufficient land to work on the father pays a pity for her daughter and gives her a piece or some pieces of land to work on.

It is this oral tradition of distributing inheritance that causes conflicts among the heirs. Only a small number of people who have been enlightened that write down a will or distribution of inheritance on a piece of paper. The initiative to write dowm an inheritance distribution on a piece of paper is from a highly educated heir who is wary of possible disputes in the family. After being read aloud the paper is signed by all the parties and witnesses.

In some families whose heirs are successful in leading their career and maintain the unity of brothers and sisters, the heirs do not care of their posisitons whether they would receive a small amount or do not receive at all. They take it for granted and give their destiny to the wisdom of the oldest heir. Then the oldest heir would choose not to comply with the tradition of the Besemah but distribute the inheritance evenly to all his brothers and sisters instead.

There are some cases in which the inheritance distribution is proclaimed before its heirs. It is proclaimed, for instance, that Sopri as the oldest son would receive a rice field and a raised house. Sopri has a good career as a judge in Java while the inheritor is still strong enough to work on his rice field, but Sopri's wife asks that after the inheritance (rice field) be distributed to Sopri, the produce of the rice field is sent to Sopri every harvest time. Based on the family's discussion on the problem, it is decided that the rice field is kept by the inheritor because the inheritor's living depends on that rice field, but Sopri's wife insists on her position. Finally Sopri's younger sister, Berlian, tries to find a 
person who wants to mortgage his rice field to her with an expectation that the share of the pawning be given to her father for his living.

\section{Things that Influence the Besemah's Customary Inheritance}

Uterine children is one factor that determines inheritance. In the Besemah's tradition, inheritors generally pass their wealth to their uterine offspring, not to step children nor to grand children. In case that all the uterine children all died eralier than the inheritor, so the inheritor does not have a living jurai, the inheritor may adopt a child — usually is still his nephew/niece-and inherit his wealth to his adopted child. This occurs to Mr. Cek Nang who was unmarried but during his life he received inheritance of a piece of rice field from his parents and before he died he made an oral will that he would like to adopt one of his niece to be his child and give his portion of inheritance to his adopted child.

A marital system chosen by a spouse determines their inheritance system. In Besemah tradition there are three kinds of marital system: belaki, ambil anak, and semendean. ${ }^{33}$ Belaki is a dominant system of marriage in Besemah. According to this system of marriage, a man that would marry a woman pays brideprice to the woman that he would marry, and after being married the spouse live in the village where her husband lives. Usually a newly married man still lives with his parents in his parents' house, but they may arrange whether to share all parts of the house or split, like the parents live in the main house while the son and daughter-in-law live in the kitchen until the newly wed couple can build their own house.

The second form of marriage is ambil anak. This form of marriage is practiced in certain condition, such as a man thatp would marry is very poor that he not only cannot pay the jujur (brideprice) but also cannot support his newly formed family in his village if he conducted the common marriage. Or in another case, the woman that he would be married is the only child of her parents. In this form of marriage, the new couple lives in the wife's village, even lives with the wife's parents (matrilocality).

The last but not least is form is semendean. According to this form of marriage, the newly wed couple determine where they would live as they like, they may live wherever they feel convenient, whether in the husband's village or in the wife's village or in different village from their parents'. In this form of marriage, a

${ }^{33}$ Interview with a number of seniors in Mulak Ulu, February 2010 . man does not pay the brideprice (jujur) as required by the marriage by berlaki (patrilocality) but does not live in the wife's family as required by the marriage of ambil anak. They live anywhere they feel convenient although it is located outside their parents' village, such as the place closer to workplace or live in the city. But this form of marriage does not influence the trasference of budel. Although they live outside their parents' village they may receive budel from the husband's father and receive inheritance from joint property of the husband's parents.

In reality, parents may reduce the number of budel for his oldest son and give a part of the budel for a daughter that marries by semendean or berlaki but then decide to go back to the wife's village because of the parents' pity for their daughter and son-in-law who live in poverty in the husband's village. ${ }^{34}$ But according to the custom's chief this is against the tradition, this can be considered as a gift but may not exceed the amount of inheritance that would be received by the legal heir. ${ }^{35}$

The customary rules of the Besemah people proves Sally Falk Moore's semi-autonomous social field, that in a society there exists semi-autonomous social field in which a society participate. This semi-autonomous social field has a tradition and has a capacity to lay rules and wisdom that people comply. But this semi-autonomous field is vulnerable to outside forces surrounding it and changes from the inside. ${ }^{36} \mathrm{As}$ a semi-autonomous social field, Besemah people have their own rule and wisdom to regulate their life. Their rule is even supported and upheld by state legal body, such as state court and to some extent by religious court. However, when people who are its subject adjudicate their cases to a religious court, judges of the religious court have their own legal reference. In this case, it is true that the rules made by the semi-autonomous social field is vulnerable to state force as an outside force.

\section{Closing Remarks}

To sum up, the type of Besemah's Islam influences the Besemah's tradition of inheritance. As Islam's influence on Besemah is limited to rituals and marriage, the Besemah's tradition is more dominant than Islamic law in the system of inheritance of the Besemah people. If an inheritance dispute is adjudicated to a state court,

\footnotetext{
${ }^{34}$ Ajun, Interview, 1 February 2010.

${ }^{35}$ Sata, Former chief of Marga Mulak Ulu, Interview, 9 February 2010.

${ }^{36}$ Sally Falk Moore, "Hukum dan Perubahan Sosial: Bidang Sosial Semi-Otonom Sebagai Suatu Topik Studi yang Tepat" dalam T.O. Ihromi (Ed.), Antropologi Hukum: Sebuah Bunga Rampai, (Jakarta: Yayasan Obor Indonesia, 2001), p. 150.
} 
judges of the state court would check the customary element of the inheritance (budel) and crimes accompanying the dispute. The state law would never check inheritance from joint property because the latter is under the jurisdiction of a religious court. Here the pluralism of law is vivid amids the society of Besemah: their own rule as a creation of a semi-autonomous social field and state rules. []

\section{Bibliography}

Abdurrahman, Kompilasi Hukum Islam di Indonesia, Jakarta: Akademika Pressindo, 1995.

Andaya, Barbara Watson, To Live As Brothers: Southeast Sumatra in the Seventeenth and Eighteenth Centuries, Hawaii: University of Hawaii Press, 1993.

Ihromi, T.O., "Beberapa Catatan mengenai Metode Kasus Sengketa yang Digunakan dalam Antropologi Hukum" dalam T.O. Ihromi (Ed.), Antropologi Hukum: Sebuah Bunga Rampai, Jakarta: Yayasan Obor Indonesia, 2001.

Irianto, Sulistyowati, Perempuan di antara Berbagai Pilihan Hukum: Studi mengenai Strategi Perempuan Batak Toba untuk Mendapatkan Akses kepada Harta Waris melalui Proses Penyelesaian Sengketa, Jakarta: Yayasan Obor Indonesia, 2012.
Jumhari, "Refleksi Historis Jati Diri dan Identitas Budaya Orang Besemah" in http://wisata-kami. blogspot.com/2009/05/refleksi-historis-jati-diridan-identitas-budaya-orang-pasemah.html.

Moore, Sally Falk, "Hukum dan Perubahan Sosial: Bidang Sosial Semi-Otonom Sebagai Suatu Topik Studi yang Tepat" dalam T.O. Ihromi (Ed.), Antropologi Hukum: Sebuah Bunga Rampai, Jakarta: Yayasan Obor Indonesia, 2001.

Peeters, Jeroen, Kaum Tuo-Kaum Mudo: Perubahan Religius di Palembang 1821-1942, Jakarta: INIS, 1997.

Rahim, Husni, "Islam di Pedalaman Palembang", makalah dalam seminar Peradaban Besemah sebagai Sarana Membangun Peradaban Bangsa, Jakarta, Mei 2010.

Soekanto, Soerjono, Hukum Adat Indonesia, Jakarta: PT RajaGrafindo Persada, 2003.

Suan, Ahmad Bastari, et al., Besemah: Lampik Mpat Mardike Duwe, Palembang: Pesake-Pemkot Pagaralam, 2008.

"Sekilas Sejarah Besemah" dalam http://besemah. blogspot.com/2007/06/sekilas-sejarah-besemah. html. 